\title{
MEDICINE
}

\section{CONDITION OF INTRACARDIAC HEMODYNAMICS AND MICROCIRCULATION IN PATIENTS WITH CHRONIC ISCHEMIC HEART DISEASE AND CONCOMITANT DIFFUSE LIVER DISEASES}

\author{
${ }^{l}$ Cardiologist, PhD Mostovyi S. \\ ${ }^{2}$ Sonologist,PhD Dynnyk $\boldsymbol{O}$. \\ ${ }^{3}$ Endocrinologist,PhD Marunchyn $N$. \\ ${ }^{1}$ Ukraine, Kyiv, Medbud Clinic. \\ ${ }^{2}$ Ukraine, Kyiv, Medical Center "Doctor Vera" \\ ${ }^{3}$ Ukraine, Kyiv, Medical Center "Institute of Elastography"
}

DOI: https://doi.org/10.31435/rsglobal_ws/30112019/6768

\section{ARTICLE INFO}

Received: 10 September 2019

Accepted: 14 November 2019

Published: 30 November 2019

\section{KEYWORDS}

ischemic heart disease, intracardiac hemodynamics, systolic and diastolic dysfunction of left ventricular,

hepatic diseases, microcirculation.

\begin{abstract}
Introduction. It is known that patients with ischemic heart diseases have endothelial dysfunction, but there is lack of research about microcirculation in these patients with diffuse liver diseases, especially diagnosed with digital capillaroscopy. Aim. To investigate hemodynamic disorders and microcirculation in patients with chronic ischemic heart disease depending on the presence of diffuse liver diseases and its severity with the digital capillaroscopy. Materials and methods. Our prospective study included 187 patients according to the criteria of inclusion. The data of echocardiography and digital capillaroscopy were analysed. Results. In our research in patients with ejection fraction less than $40 \%$ there was revealed thickening of the wall of the left ventricle, low blood supply in arterial and venous parts of capillaries. Patients with ejection fraction less than $40 \%$ and progressive diffuse liver diseases had advanced thickening of the wall of the left ventricle. Patients with liver cirrhosis had more adverse changes in hemodynamics. Patients with ischemic heart disease and diffuse liver disease had the worst capillary blood supply. Patients with ejection fraction less than $40 \%$ and diffuse liver diseases had structural changes of capillaries such as bi-, trifurcation and bushy forms. Conclusions. So, diffuse liver diseases, especially severe, cause endothelial dysfunction in patients with ischemic heart diseases. Digital capillaroscopy is a noninvasive method for microcirculation diagnosis and patients' monitoring.
\end{abstract}

Citation: Mostovyi S., Dynnyk O., Marunchyn N. (2019) Condition of Intracardiac Hemodynamics and Microcirculation in Patients with Chronic Ischemic Heart Disease and Concomitant Diffuse Liver Diseases. World Science. 11(51), Vol.2. doi: 10.31435/rsglobal_ws/30112019/6768

Copyright: (C) 2019 Mostovyi S., Dynnyk O., Marunchyn N. This is an open-access article distributed under the terms of the Creative Commons Attribution License (CC BY). The use, distribution or reproduction in other forums is permitted, provided the original author(s) or licensor are credited and that the original publication in this journal is cited, in accordance with accepted academic practice. No use, distribution or reproduction is permitted which does not comply with these terms.

Introduction. Capillaroscopy is a noninvasive method of microcirculation (MC) investigation [1-3] and is widely used in patients with ischemic heart disease (IHD), but there are only few scientific works about MC in patients with IHD and concomitant diffuse liver diseases (DLD).

Aim. To investigate hemodynamic dysfunction and microcirculation in patients with chronic IHD depending on concomitant DLD with digital capillaroscopy.

Materials and methods. We conducted open prospective investigation in the Medical center 'Doctor Vera' and diagnostic department of Medbud Clinic from 2009 till 2019. Patients were selected 
in the study according to the criteria of inclusion: presence of IHD and DLD. There was one more group with 30 healthy volunteers. The investigation was conducted according to the standards of Good Clinical Practice, Ukrainian medical law and all patients signed informed agreement. 187 patients were included in the study - 34 women and 154 men from 18 to 85 years old (average age was $46,1 \pm 17,4)$. There were three groups in our study.

The first group included 55 patients with chronic IHD and with chronic heart insufficiency (CHI) III B stages, I-IV functional classes, average age $61,5 \pm 12,8$ and there were 16 women (29\%) with ejection fraction of the left ventricle (EFlv) 44,2 $\pm 8,6 \%$ (Table 1). The average duration of IHD was 8,2 $\pm 5,7$ years. The first group was divided into subgroups A and B depending on the presence (1B) or absence (1A) of the DLD. The subgroup 1B included the following DLD: $5(20 \%)$ patients with chronic toxic hepatitis (CTH), $14(56 \%)$ - nonalcoholic steatohepatitis (NASH), $5(20 \%)$ - chronic viral hepatitis (CVH) B and C (CVHB, CVHC), $3(12 \%)$ - liver cirrhosis (LC) A-B classes according to Child-Pugh, 3 (12\%) - cryptogenic hepatitis. More than one third of the patients with IHD had myocardial infarction. All the patients had concomitant hypertensive disease. Patients with NASH had insulin-independing type 2diabetes mellitus.

Table 1. Data of the patients with IHD

\begin{tabular}{|l|l|l|l|l|}
\hline \multirow{2}{*}{$\begin{array}{l}\text { № } \\
\Pi / \Pi\end{array}$} & Data & \multicolumn{3}{|c|}{1 group $(\mathrm{n}=55)$} \\
\cline { 3 - 5 } & In general & $1 \mathrm{~A} \mathrm{n}=30$ & $1 \mathrm{5} \mathrm{n=25}$ \\
\hline 1 & Age (years) & $61,5 \pm 12,8$ & $60,2 \pm 11,0$ & $58,8 \pm 12,4$ \\
\hline 2 & $\%$ men & $71 \%(39)$ & $63,3 \%(19)$ & $80 \%(20)$ \\
\hline 3 & Hypertensive disease & $100 \%(55)$ & $100 \%(30)$ & $100 \%(25)$ \\
\hline 4 & Ventricular extrasystoles & $11 \%(6)$ & $10 \%(3)$ & $12 \%(3)$ \\
\hline 6 & Type 2 diabetes mellitus & $22 \%(12)$ & $30 \%(10)^{*}$ & $8 \%(2)$ \\
\hline 6 & $\begin{array}{l}\text { Myocardial infarction in anamnesis of } \\
\text { disease }\end{array}$ & $42 \%(23)$ & $50 \%(15)$ & $32 \%(8)$ \\
\hline 7 & $\begin{array}{l}\text { Acute disturbances of cerebral blood } \\
\text { circulation/Transient ischemic attack } \\
\text { in anamnesis of disease }\end{array}$ & $3,6 \%(4)$ & $6,6 \%(2)$ & $8 \%(2)$ \\
\hline
\end{tabular}

Abbreviations: ${ }^{*} \mathrm{p}<0,05$ comparing within groups. Continuous variables were expressed as mean \pm SD. Categorial variables were expressed as percentage.

The second group included 102 patients with DLD, average age was 37,3 $\pm 15,2$ years: 12 patients with LC, average age was $45,1 \pm 9,2$ years; 43 patients with CVH: 6 women, average age was $31,8 \pm 8,9$ years, 12 patients with CVHB, 24 patients with CVHC, 4 patients with CVHB $+\mathrm{C}, 2$ patients with viral hepatitis Epstein-Barr, 1 patient with CVB TTV; 21 patients with chronic toxic hepatitis of

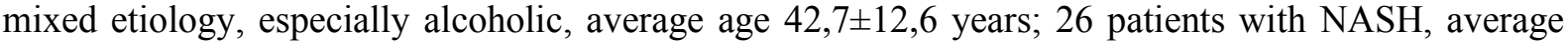
age $40,8 \pm 10,0$ years. We also analysed the data of the patients in the second group according to the stages of liver diseases: subgroup A - 48 patients with minimal cytolytic syndrome and cholestasis (elevation of alaninaminotransferase (ALT) less than in 5 times; bilirubin was less than $100 \mathrm{mcmol} / \mathrm{l}$ ); subgroup B - 42 patients with moderate syndrome of cytolysis and cholestasis (elevation of ALT in 510 times, bilirubin from 100 to $200 \mathrm{mcmol} / \mathrm{l})$; subgroup B - 12 patients with LC.

The third group included 30 healthy volunteers ( 8 women $(25,7 \%)$ and 22 men $(74,3 \%)$ ), average age $33,5 \pm 8,4$ years.

Transthoracic echocardiography (echo) was conducted on the device HDI 11XE Philips according to the general methodology [1] with measurement in 2D-regime of wall thickness of the right ventricle (Trv), posterior wall of the LV (Tlv), intraventricular septum (Tivs), short-axis size of the left atrium (LA), terminal diastolic volume (TDV) of LV by Simpson, its EF and also short-axis size of the RV in basal chamber (Drv(k)), diameter of vena cava inferior (VCI). Diastolic filling of the LV was evaluated according to the ratio of transmitral flow velocity in the period of rapid filling and in systolic phase of the LA (E/A), time of decreasing of early diastolic filling velocity (DT) and duration of the period of left ventricular isometric relaxation (IVRT). Systolic pressure of the pulmonary artery (SPpa) was evaluated by the speed of tricuspid regurgitation flow.

Digital capillaroscopy (DC) was conducted on the device OOO «Micropotic» Kyiv with the programme AngioPro. The following data of DC were measured: diameter of the arterial part of the capillary (DAC), diameter of the venous part of the capillary (DVC), length of the arterial part (LAC) and venous part (LVC) of the capillary, blood flow velocity of the arterial part (FVAC) and venous part of the capillary (FVVC). 
Statistical analyses was made with Statistica for Windows 7.0 (Statsoft, USA). Distribution of the values wasexpressed as median, mean and Shapiro-Wilk criterion. Comparing groups was held with Vilkokson-Mann-Witney criterion. Reliability of nonparametric data discrepancies in groups (including follow-up period) was made with Chi-square criterion. Correlation analyses was made with Pearson's correlation croterion. The discrepancies were statistically significant at $p<0,05$.

Results and discussion. According to the recommendations of the Ukrainian association of cardiologists of diagnosis, treatment and prevention of CHI in adults (2017) we divided our patients into two groups: group 1 with normal $\mathrm{EF}$ of the LV systolic function (EFlv $>40 \%)$ and group 2 with reduced EF (EFlv $<40 \%)$. For additional evaluation of the stage of diastolic dysfunction of LV we created subgroups with E/A more and less than 1 in every group. We evaluated the fact that $E / A>1,0$ at $\mathrm{EFlv}<40 \%$ was related to the pseudonormal/restricrive type of transmitral flow and in case of EFlv $>40 \% \mathrm{E} / \mathrm{A}>1,0$ better diastolic filling of $\mathrm{LV}$ was performed comparing the patients with $\mathrm{E} / \mathrm{A}<1,0$ (diastolic dysfunction of the LV by relaxation disorder type). Part of the patients with concomitant DLD among the patients with EFlv $>40 \%$ was $41 \%$ and among the patients with EFlv $<40 \%-50 \%$.

The data of intracardiac hemodynamics of the both groups confirmed the dilatation of the ventricles and LA, thickening of the ventricles' walls, increasing of the pressure in the pulmonary artery, size of the VCI (Table 2). Patients with EFlv $<40 \%$ had elevated data of TDV, Tivs, Tlv, SPpa, VCI comparing to the patients with EFlv $>40 \%$. Patients with EFlv $>40 \%$ and E/A $>1,0$ had less thickening of the walls of LV and this provd the dependence of LV rigidity from the thickness of its walls. Patients with EFlv $<40 \%$ and E/A $>1,0$ had higher data of TDV and LA and lower data of IVRT i DT comparing to the subgroup with $\mathrm{EFlv}<40 \%$ and $\mathrm{E} / \mathrm{A}<1,0$ which proved the increased load of the ventricles and LA at pseudonormal and restrictive types of diastolic dysfunction.

Table 2. Data of echo in patients with IHD depending on the condition of systolic and diastolic functions of LV

\begin{tabular}{|c|c|c|c|c|c|c|c|}
\hline $\begin{array}{l}\text { Data of } \\
\text { EchoKG } \mathrm{M} \pm \mathrm{SD}\end{array}$ & $\begin{array}{c}E F>40 \% \\
(n=14)\end{array}$ & $\begin{array}{c}E F>40 \% \\
E / A>1,0 \\
(n=9)\end{array}$ & $\begin{array}{c}E F>40 \% \\
E / A<1,0 \\
(n=5)\end{array}$ & $\begin{array}{c}\mathrm{EF}<40 \% \\
(\mathrm{n}=16)\end{array}$ & $\begin{array}{c}E F<40 \% \\
E / A>1,0 \\
(n=10)\end{array}$ & $\begin{array}{c}\mathrm{EF}<40 \% \\
\mathrm{E} / \mathrm{A}<1,0 \\
(\mathrm{n}=6)\end{array}$ & $\begin{array}{l}\text { Healthy } \\
\text { volunteers } \\
(\mathrm{n}=30)\end{array}$ \\
\hline Trv, cm & $\begin{array}{l}0,40 \pm \\
0,14^{*}\end{array}$ & $\begin{array}{l}0,40 \pm \\
0,11^{*}\end{array}$ & $\begin{array}{l}0,40 \pm \\
0,15^{*}\end{array}$ & $\begin{array}{l}0,44 \pm \\
0,13^{*}\end{array}$ & $\begin{array}{c}0,45 \pm \\
0,14^{*}\end{array}$ & $\begin{array}{l}0,44 \pm \\
0,13^{*}\end{array}$ & $0,32 \pm 0,11$ \\
\hline $\mathrm{LA}, \mathrm{cm}$ & $4,37 \pm 0,62^{*}$ & $\begin{array}{l}4,45 \pm \\
0,55^{*}\end{array}$ & $\begin{array}{l}4,37 \pm \\
0,69^{*}\end{array}$ & $\begin{array}{l}4,47 \pm \\
0,50^{*}\end{array}$ & $\begin{array}{l}4,66 \pm \\
0,68^{*}\end{array}$ & $\begin{array}{l}4,38 \pm \\
0,36^{*}\end{array}$ & $3,62 \pm 0,09$ \\
\hline Tivs, cm & $\begin{array}{l}1,01 \pm \\
0,09^{*}\end{array}$ & $\begin{array}{l}0,95 \pm \\
0,06^{* \dagger}\end{array}$ & $\begin{array}{l}1,05 \pm \\
0,09^{*}\end{array}$ & $\begin{array}{l}1,05 \pm \\
0,11^{*}\end{array}$ & $\begin{array}{l}1,04 \pm \\
0,10^{*}\end{array}$ & $\begin{array}{l}1,06 \pm \\
0,12^{*}\end{array}$ & $0,88 \pm 0,07$ \\
\hline Tlv, cm & $1,01 \pm 0,11$ & $\begin{array}{l}0,98 \pm \\
0,07 * \dagger\end{array}$ & $\begin{array}{l}1,03 \pm \\
0,09^{*}\end{array}$ & $\begin{array}{l}1,05 \pm \\
0,12^{*}\end{array}$ & $\begin{array}{l}1,05 \pm \\
0,13^{*}\end{array}$ & $\begin{array}{l}1,05 \pm \\
0,12^{*}\end{array}$ & $0,88 \pm 0,06$ \\
\hline EFlv,\% & $\begin{array}{l}51,7 \pm \\
5,2 * \S\end{array}$ & $\begin{array}{c}50,3 \pm \\
5,4^{*}\end{array}$ & $\begin{array}{l}51,4 \pm \\
6,3^{*}\end{array}$ & $\begin{array}{c}37,6 \pm \\
5,1^{*}\end{array}$ & $\begin{array}{l}37,8 \pm \\
4,12 *\end{array}$ & $\begin{array}{c}37,5 \pm \\
5,6^{*}\end{array}$ & $67,4 \pm 2,5$ \\
\hline TDV, ml & $165 \pm 25^{* \S}$ & $161 \pm 31 *$ & $163 \pm 33 *$ & $185 \pm 43^{*}$ & $211 \pm 46^{* \dagger}$ & $172 \pm 32 *$ & $121 \pm 24$ \\
\hline E/Alv & $\begin{array}{c}0,89 \pm \\
0,33^{*}\end{array}$ & $\begin{array}{c}1,29 \pm \\
0,29^{\dagger}\end{array}$ & $\begin{array}{l}0,72 \pm \\
0,17^{*}\end{array}$ & $\begin{array}{c}0,96 \pm \\
0,56\end{array}$ & $\begin{array}{c}1,49 \pm \\
0,67^{\dagger}\end{array}$ & $\begin{array}{l}0,72 \pm \\
0,15^{*}\end{array}$ & $1,34 \pm 0,12$ \\
\hline IVRT,ms & $95 \pm 15^{*}$ & $86 \pm 15^{\dagger}$ & $99 \pm 13^{*}$ & $93 \pm 13^{*}$ & $86 \pm 11^{\dagger}$ & $96 \pm 12^{*}$ & $81,5 \pm 2,1$ \\
\hline $\mathrm{DT}, \mathrm{ms}$ & $196 \pm 35^{*}$ & $181 \pm 29$ & $199 \pm 33^{*}$ & $190 \pm 41^{*}$ & $155 \pm 25^{* \dagger}$ & $209 \pm 35^{*}$ & $179 \pm 14$ \\
\hline SPpa,mm Hg & $30,0 \pm 4,1^{*} \S$ & $\begin{array}{c}30,7 \pm \\
6,0^{*}\end{array}$ & $\begin{array}{c}29,8 \pm \\
3,3^{*}\end{array}$ & $\begin{array}{c}34,5 \pm \\
7,7^{*}\end{array}$ & $\begin{array}{l}37,3 \pm \\
10,5^{*}\end{array}$ & $\begin{array}{c}33,0 \pm \\
5,3^{*}\end{array}$ & $26,3 \pm 0,6$ \\
\hline $\begin{array}{l}\text { DiameterRV(k), } \\
\mathrm{cm}\end{array}$ & $\begin{array}{l}2,51 \pm \\
0,45^{*}\end{array}$ & $\begin{array}{l}2,60 \pm \\
0,70^{*}\end{array}$ & $\begin{array}{l}2,48 \pm \\
0,31^{*}\end{array}$ & $\begin{array}{l}2,58 \pm \\
0,36^{*}\end{array}$ & $\begin{array}{l}2,69 \pm \\
0,55^{*}\end{array}$ & $\begin{array}{l}2,53 \pm \\
0,21 *\end{array}$ & $2,12 \pm 0,10$ \\
\hline VCI, cm & $2,07 \pm 0,21^{*}$ & $\begin{array}{l}2,07 \pm \\
0,23^{*}\end{array}$ & $\begin{array}{l}2,07 \pm \\
0,21^{*}\end{array}$ & $\begin{array}{l}2,19 \pm \\
0,36^{*}\end{array}$ & $\begin{array}{l}2,53 \pm \\
0,46^{* \dagger}\end{array}$ & $\begin{array}{l}2,13 \pm \\
0,22 *\end{array}$ & $1,80 \pm 0,30$ \\
\hline
\end{tabular}

Abbreviations: $* \mathrm{p}<0,05$ comparing to control group.

${ }^{\S} \mathrm{p}<0,05$ comparing groups with EFlv.

" $<<0,05$ comparing with patients with $\mathrm{E} / \mathrm{A}<1,0$ at the same EFlv.

We have analysed the data of DC in patients with IHD (Table 3) and have found decrease of DAC, DVC, FVAC and FVVC which proved the reduction of capillary flow as a result of mio- and neurotone elevation, peripheral resistance venous outflow dysfunction due to $\mathrm{CHI}$. In patients with EFlv $<40 \%$ decreased data of FVAC and FVVC demonstrated the reduction of blood supply of 
microcirculation due to [4] reduced cardiac output and blood volume in capillaries and elevation of tone of vessels of middle and small calibres as a result of activated sympathetic-adrenal system (SAS), renin-angiotensin-aldosterone system and hyperproduction of vasoconstrictors [5].

Table 3. Data of DC in patients with IHD depending on the condition of systolic and diastolic functions.

\begin{tabular}{|l|c|c|c|c|c|}
\hline $\begin{array}{c}\text { Data of DC } \\
\mathrm{M} \pm \mathrm{SD}\end{array}$ & $\begin{array}{c}\mathrm{EF}>40 \% \\
\mathrm{E} / \mathrm{A}>1,0 \\
(\mathrm{n}=9)\end{array}$ & $\begin{array}{c}\mathrm{EF}>40 \% \\
\mathrm{E} / \mathrm{A}<1,0 \\
(\mathrm{n}=5)\end{array}$ & $\begin{array}{c}\mathrm{EF}<40 \% \\
\mathrm{E} / \mathrm{A}>1,0 \\
(\mathrm{n}=10)\end{array}$ & $\begin{array}{c}\mathrm{EF}<40 \% \\
\mathrm{E} / \mathrm{A}<1,0 \\
(\mathrm{n}=6)\end{array}$ & $\begin{array}{c}\text { Healthy } \\
\text { volunteers } \\
(\mathrm{n}=30)\end{array}$ \\
\hline $\mathrm{DAC}, \mathrm{mcm}$ & $11,8 \pm 4,1^{\dagger}$ & $8,3 \pm 2,4^{*}$ & $7,1 \pm 3,5^{*}$ & $9,3 \pm 2,6^{*}$ & $12,5 \pm 2,3$ \\
\hline $\mathrm{DVC}, \mathrm{mcm}$ & $14,2 \pm 5,3$ & $11,4 \pm 5,1^{*}$ & $13,3 \pm 4,7^{*}$ & $14,5 \pm 3,1$ & $15,1 \pm 3,9$ \\
\hline $\mathrm{LAC}, \mathrm{mcm}$ & $228(182-373)$ & $304(183-406)^{*}$ & $212(275-510)^{*}$ & $312(190-475)^{*}$ & $402(207-611)$ \\
\hline $\mathrm{LVC}, \mathrm{mcm}$ & $237(190-388)$ & $315(202-423)$ & $270(201-603)^{*}$ & $320(185-405)^{*}$ & $455(216-701)$ \\
\hline FVAC, $\mathrm{mcm} / \mathrm{s}$ & $408(181-650)^{*}$ & $370(227-584)^{*}$ & $340(130-509)^{*}$ & $315(122-439)^{*}$ & $612(349-950)$ \\
\hline FVVC, $\mathrm{mcm} / \mathrm{c}$ & $381(145-473)^{*}$ & $290(121-405)^{*}$ & $264(120-343)^{*}$ & $270(219-431)^{*}$ & $560(350-890)$ \\
\hline
\end{tabular}

Abbreviations: continuous variables were expressed as median (interquartile range).

$\mathrm{u}$ - Vilkokson-Mann-Witney criterion.

$* \mathrm{u}<0,05$ comparing to the healthy volunteers.

${ }^{\S} \mathrm{u}<0,05$ comparing groups with different data of EFlv.

${ }^{\dagger} \mathrm{u}<0,05$ comparing with patients with $\mathrm{E} / \mathrm{A}<1,0$ at the similar EFlv.

The results of echo investigation in the groups are presented in Table 4. All the patients with IHD had enlargement of cavity and thickening of the wall of LV with its contraction dysfunction and diastolic filling, enlargement of cavity and thickening of the wall of RV, enlargement of the LA and VCI, elevation of pressure in the PA. Patients with IHD had higher degree of dysfunction of structural and functional changes of different heart chambers comparing to the patients with DLD. Patients with IHD and concomitant DLD had higher data of Trv, EFlv and lower data of TDVlv.

Table 4. Distribution of echo data

\begin{tabular}{|l|c|c|c|c|}
\hline $\begin{array}{l}\text { Data of echo } \\
(\mathrm{M} \pm \mathrm{SD})\end{array}$ & $\begin{array}{c}\text { IHD } \\
\mathrm{N}=30\end{array}$ & $\begin{array}{c}\text { IHD + DLD } \\
\mathrm{n}=25\end{array}$ & $\begin{array}{c}\text { DLD } \\
\mathrm{n}=102\end{array}$ & $\begin{array}{c}\text { Healthy volunteers } \\
\mathrm{n}=30\end{array}$ \\
\hline Trv, cm & $0,38 \pm 0,02$ & $0,48 \pm 0,12^{* \wedge}$ & $0,43 \pm 0,01^{* \wedge}$ & $0,32 \pm 0,11$ \\
\hline LA, cm & $4,45 \pm 0,09^{*}$ & $4,39 \pm 0,07^{*}$ & $3,90 \pm 0,04^{\wedge}$ & $3,62 \pm 0,09$ \\
\hline Tivs, cm & $1,02 \pm 0,03^{*}$ & $1,05 \pm 0,01^{*}$ & $0,95 \pm 0,01^{* \wedge}$ & $0,88 \pm 0,07$ \\
\hline Tlv, cm & $1,02 \pm 0,02^{*}$ & $1,05 \pm 0,01^{* \wedge}$ & $0,96 \pm 0,01^{* \wedge}$ & $0,88 \pm 0,06$ \\
\hline EFlv, \% & $44,1 \pm 8,6^{*}$ & $46,1 \pm 8,9^{*}$ & $64,5 \pm 0,4^{* \wedge}$ & $67,4 \pm 2,5$ \\
\hline TDVlv, ml & $176 \pm 33^{*}$ & $170 \pm 44^{*}$ & $128 \pm 12^{\wedge}$ & $121 \pm 24$ \\
\hline E/Alv & $0,82 \pm 0,41^{*}$ & $0,98 \pm 0,48^{*}$ & $1,06 \pm 0,03^{* \wedge}$ & $1,34 \pm 0,12$ \\
\hline IVRT, ms & $94,5 \pm 16,2^{*}$ & $94,4 \pm 10,0^{*}$ & $85,1 \pm 1,3^{\wedge \#}$ & $81,5 \pm 2,1$ \\
\hline DT, ms & $199 \pm 25^{*}$ & $186 \pm 43$ & $181 \pm 13^{\wedge}$ & $179 \pm 14$ \\
\hline SPpa, mmHg & $32,1 \pm 0,8^{*}$ & $32,0 \pm 1,0^{*}$ & $29,6 \pm 0,4^{* \wedge}$ & $26,3 \pm 0,6$ \\
\hline DiameterRV(k), cm & $2,49 \pm 0,06^{*}$ & $2,59 \pm 0,05^{*}$ & $2,53 \pm 0,04^{*}$ & $2,12 \pm 0,10$ \\
\hline VCI, cm & $2,06 \pm 0,03$ & $2,21 \pm 0,05^{*}$ & $2,23 \pm 0,21^{* \wedge}$ & $1,80 \pm 0,30$ \\
\hline
\end{tabular}

Abbreviations: Continuous variables were expressed as mean \pm SD.

${ }^{*} \mathrm{p}<0,05$ comparing to the healthy volunteers.

$\wedge \mathrm{p}<0,05$ comparing to the patients with IHD.

${ }^{*} \mathrm{p}<0,05$ comparing to the patients with IHD and DLD.

We analyzed the data of echo of our patients with IHD and concomitant DLD according to the similar data of EFlv because it was difficult to evaluate classical clinical criteria of heart insufficiency such as stuffiness, tachycardia, hepatomegaly, oedema, ascites, hydrothorax etc. (Table 5). Patients with IHD and EFlv $>40 \%$ and with DLD had thickening of the walls of the ventricles at analyzing the data of echo. Patients with EFlv $<40 \%$ and DLD had significantly advanced thickness of the wall, short size of the RV and diameter of VCI. The main cause of the remodeling processes of RV and LV could be changes of metabolism of vasoactive factors and liver hemodynamic dysfunction. 
Table 5. Data of echo in patients with IHD and DLD to the similar data of EFlv

\begin{tabular}{|c|c|c|c|c|c|}
\hline \multirow[t]{2}{*}{ Data of echo } & \multicolumn{2}{|c|}{ IHD EFlv $>40 \%$} & \multicolumn{2}{|c|}{ IHD EFlv<40\% } & \multirow{2}{*}{$\begin{array}{c}\text { Healthy } \\
\text { volunteers }\end{array}$} \\
\hline & with DLD & without DLD & with DLD & without DLD & \\
\hline $\mathrm{M} \pm \mathrm{SD}$ & $\mathrm{N}=13$ & $\mathrm{n}=14$ & $\mathrm{n}=12$ & $\mathrm{n}=16$ & $\mathrm{n}=30$ \\
\hline Trv, cm & $0,45 \pm 0,13^{* \dagger}$ & $0,37 \pm 0,13$ & $0,48 \pm 0,13^{* \dagger}$ & $0,40 \pm 0,12 *$ & $0,32 \pm 0,11$ \\
\hline $\mathrm{LA}, \mathrm{cm}$ & $4,36 \pm 0,44^{*}$ & $4,42 \pm 0,78^{*}$ & $4,47 \pm 0,53 *$ & $4,47 \pm 0,48^{*}$ & $3,62 \pm 0,09$ \\
\hline Tivs, cm & $1,05 \pm 0,11^{* \dagger}$ & $1,00 \pm 0,08 *$ & $1,06 \pm 0,11 *$ & $1,03 \pm 0,11 *$ & $0,88 \pm 0,07$ \\
\hline $\mathrm{Tlv}, \mathrm{cm}$ & $1,05 \pm 0,11^{* \dagger}$ & $0,99 \pm 0,07 *$ & $1,07 \pm 0,12 *$ & $1,04 \pm 0,12 *$ & $0,88 \pm 0,06$ \\
\hline EFlv, \% & $52,6 \pm 8,2 *$ & $50,2 \pm 3,3^{*}$ & $39,9 \pm 3,5^{* \dagger}$ & $35,0 \pm 5,4^{*}$ & $67,4 \pm 2,5$ \\
\hline TDVlv, ml & $163 \pm 37 *$ & $165 \pm 29 *$ & $177 \pm 50 *$ & $194 \pm 33^{*}$ & $121 \pm 24$ \\
\hline E/Alv & $0,90 \pm 0,27^{*}$ & $0,86 \pm 0,37 *$ & $1,05 \pm 0,62 *$ & $0,87 \pm 0,48 *$ & $1,34 \pm 0,12$ \\
\hline IVRT, ms & $93 \pm 10 *$ & $97 \pm 17 *$ & $94 \pm 9 *$ & $91 \pm 15^{*}$ & $81,5 \pm 2,1$ \\
\hline $\mathrm{DT}, \mathrm{ms}$ & $189 \pm 36^{*}$ & $197 \pm 31 *$ & $184 \pm 49$ & $198 \pm 29 *$ & $179 \pm 14$ \\
\hline SPpa, mmHg & $29,8 \pm 3,4 *$ & $30,2 \pm 4,6^{*}$ & $34,0 \pm 7,9 *$ & $35,0 \pm 7,5^{*}$ & $26,3 \pm 0,6$ \\
\hline DiameterRV(k), cm & $2,55 \pm 0,25^{*}$ & $2,48 \pm 0,55^{*}$ & $2,67 \pm 0,44^{* \dagger}$ & $2,49 \pm 0,22 *$ & $2,12 \pm 0,10$ \\
\hline $\mathrm{VCI}, \mathrm{cm}$ & $2,12 \pm 0,12^{*}$ & $2,04 \pm 0,22 *$ & $2,27 \pm 0,44^{* \dagger}$ & $2,10 \pm 0,23 *$ & $1,80 \pm 0,30$ \\
\hline
\end{tabular}

Abbreviations: Continuous variables were expressed as mean \pm SD.

${ }^{*} \mathrm{p}<0,05$ comparing to the healthy volunteers.

${ }^{\dagger} \mathrm{p}<0,05$ comparing to the patients with IHD and without DLD at the similar data of EFlv.

We analysed the data of echo in patients with DLD depending on the liver damage for understanding the influence of concomitant DLD on the condition of hemodynamics in patients with IHD (Table 6). The worst prognostic data were revealed in patients with LC.

Table 6. Data of echo in patients with DLD depending on the etiology

\begin{tabular}{|l|c|c|c|c|c|}
\hline Data of echo & $\begin{array}{c}\text { Normal } \\
\mathrm{n}=30\end{array}$ & $\begin{array}{c}\text { NASH } \\
\mathrm{n}=26\end{array}$ & $\begin{array}{c}\text { CTH } \\
\mathrm{N}=21\end{array}$ & $\begin{array}{c}\text { CVH } \\
\mathrm{n}=43\end{array}$ & $\begin{array}{c}\text { LC } \\
\mathrm{n}=12\end{array}$ \\
\hline Trv, cm & $0,32 \pm 0,11$ & $0,41 \pm 0,11^{\wedge}$ & $0,44 \pm 0,40^{\wedge}$ & $0,40 \pm 0,09^{*} \wedge$ & $0,57 \pm 0,11^{*}$ \\
\hline LA, cm & $3,62 \pm 0,09$ & $4,10 \pm 0,37^{*}$ & $3,90 \pm 0,36^{*} \wedge$ & $3,73 \pm 0,33^{* \wedge}$ & $4,24 \pm 0,51^{*}$ \\
\hline Tivs, cm & $0,88 \pm 0,07$ & $0,99 \pm 0,14^{*}$ & $0,95 \pm 0,10^{\wedge}$ & $0,92 \pm 0,08^{\wedge}$ & $1,02 \pm 0,11^{*}$ \\
\hline Tlv, cm & $0,88 \pm 0,06$ & $0,98 \pm 0,11$ & $0,97 \pm 0,10^{*} \wedge$ & $0,92 \pm 0,08^{*} \wedge$ & $1,02 \pm 0,14^{*}$ \\
\hline EFlv, \% & $67,4 \pm 2,5$ & $64,4 \pm 4,6$ & $64,9 \pm 2,5$ & $66,0 \pm 2,9^{\wedge}$ & $63,3 \pm 4,8^{*}$ \\
\hline TDVlv, ml & $121 \pm 24$ & $132 \pm 16^{*}$ & $126 \pm 20^{*}$ & $123 \pm 20^{\wedge}$ & $136 \pm 21$ \\
\hline E/Alv & $1,34 \pm 0,12$ & $0,96 \pm 0,21^{*}$ & $1,03 \pm 0,24^{*}$ & $1,18 \pm 0,30^{*} \wedge$ & $0,86 \pm 0,22^{*}$ \\
\hline IVRT, ms & $81,5 \pm 2,1$ & $89,0 \pm 10,0$ & $87,1 \pm 12,0$ & $80,6 \pm 12,1$ & $89,8 \pm 14,0$ \\
\hline DT, ms & $179 \pm 14$ & $173 \pm 31^{* \wedge}$ & $178 \pm 37$ & $181 \pm 30$ & $197 \pm 36$ \\
\hline SPpa, mmHg & $26,3 \pm 0,6$ & $27,3 \pm 2,7^{\wedge}$ & $29,5 \pm 2,5^{*}$ & $29,5 \pm 4,8^{*}$ & $33,9 \pm 4,5^{*}$ \\
\hline DiameterRV(k), cm & $2,12 \pm 0,10$ & $2,50 \pm 0,26$ & $2,50 \pm 0,20^{*}$ & $2,49 \pm 0,33^{* \wedge}$ & $2,91 \pm 0,43^{*}$ \\
\hline VCI, cm & $1,80 \pm 0,30$ & $2,14 \pm 0,33^{*}$ & $2,20 \pm 0,18^{*}$ & $2,20 \pm 0,22^{*}$ & $2,55 \pm 0,21^{*}$ \\
\hline
\end{tabular}

Abbreviations: Continuous variables were expressed as mean \pm SD.

$* \mathrm{p}<0.05$, comparing to the controls.

${ }^{\wedge} \mathrm{p}<0,05$ comparing to the group with LC.

In our study the most significant changes of hemodynamics were revealed in patients with LC and included the enlargement of the walls and cavity of the ventricles, dysfunction of contraction and filling of the left ventricle, dilatation of the left atrium, pulmonary hypertension (Table 7).

Table 7. Data of echo with DLD to the damage degree

\begin{tabular}{|l|c|c|c|c|}
\hline \multicolumn{1}{|c|}{$\begin{array}{c}\text { Data of echo } \\
\text { M } \pm \text { SD }\end{array}$} & $\begin{array}{c}\mathrm{LC} \\
\mathrm{n}=12\end{array}$ & $\begin{array}{c}\text { DLD with moderate } \\
\text { degree of damage } \\
\mathrm{n}=38\end{array}$ & $\begin{array}{c}\text { DLD with minimal } \\
\text { degree of damage } \\
\mathrm{n}=52\end{array}$ & $\begin{array}{c}\text { Healthy } \\
\text { volunteers } \\
\mathrm{n}=30\end{array}$ \\
\hline 1 & 2 & 3 & 4 & 5 \\
\hline Trv, cm & $0,57 \pm 0,11^{*}$ & $0,40 \pm 0,10^{\wedge}$ & $0,41 \pm 0,12^{\wedge}$ & $0,32 \pm 0,11$ \\
\hline LA, cm & $4,24 \pm 0,51^{*}$ & $3,69 \pm 0,33^{\wedge}$ & $3,96 \pm 0,56^{\wedge}$ & $3,62 \pm 0,09$ \\
\hline Tivs, cm & $1,02 \pm 0,11^{*}$ & $0,91 \pm 0,08^{\wedge}$ & $0,96 \pm 0,11^{*}$ & $0,88 \pm 0,07$ \\
\hline Tlv, cm & $1,02 \pm 0,14^{*}$ & $0,91 \pm 0,07^{\wedge}$ & $0,97 \pm 0,10^{*}$ & $0,88 \pm 0,06$ \\
\hline EFlv, $\%$ & $63,3 \pm 4,8^{*}$ & $66,1 \pm 3,1^{*}$ & $64,8 \pm 3,9^{*}$ & $67,4 \pm 2,5$ \\
\hline TDVlv, $\mathrm{ml}$ & $136 \pm 21$ & $122 \pm 21^{\wedge}$ & $129 \pm 18^{\wedge}$ & $121 \pm 24$ \\
\hline
\end{tabular}


Continuation of table 7.

\begin{tabular}{|l|c|c|c|c|}
\hline \multicolumn{1}{|c|}{1} & 2 & 3 & 4 & 5 \\
\hline E/Alv & $0,86 \pm 0,22^{*}$ & $1,17 \pm 0,52^{\wedge}$ & $1,03 \pm 0,27^{* \wedge}$ & $1,34 \pm 0,12$ \\
\hline IVRT, ms & $89,8 \pm 14,0$ & $81,6 \pm 13,8$ & $86,3 \pm 10,9$ & $81,5 \pm 2,1$ \\
\hline DT, ms & $197 \pm 36$ & $184 \pm 32$ & $176 \pm 30^{\wedge}$ & $179 \pm 14$ \\
\hline SPpa, mmHg & $33,9 \pm 4,5^{*}$ & $30,5 \pm 3,2^{* \wedge}$ & $28,0 \pm 2,9^{* \wedge}$ & $26,3 \pm 0,6$ \\
\hline DiameterRV(k), cm & $2,91 \pm 0,43^{*}$ & $2,58 \pm 0,37^{* \wedge}$ & $2,41 \pm 0,21^{* \wedge}$ & $2,12 \pm 0,10$ \\
\hline VCI, cm & $2,55 \pm 0,21^{*}$ & $2,19 \pm 0,22^{* \wedge}$ & $2,18 \pm 0,25^{* \wedge}$ & $1,80 \pm 0,30$ \\
\hline
\end{tabular}

Abbreviations: Continuous variables were expressed as mean $\pm \mathrm{SD}$.

$* p<0,05$ comparing to the healthy.

$\wedge p<0,05$ comparing to the group with LC.

\# $\mathrm{p}<0,05$ comparing to the patients with minimal damage.

According to the results of DC (Table 8) in patients with IHD and without DLD there was reduction of LAC, LVC, FVAC and FVVC due to the elevation of SAS and local peripheral resistance [6]. Patients with DLD had decreased FVAC and FVVC as the result of the remodeling of capillary flow. Patients with IHD and DLD had higher stage of capillary flow disorder due to the production of inflammatory cytokines and disturbances of its utilization by the liver. We also revealed in our study that there was different pathomorphology of capillary flow changes. Patients with IHD and DLD had long forms because of elevation of peripheral resistanse, spasm of precapillary sphincters and activation of SAS. Patients with DLD had more tortuous and distorted short capillary loops which proved the dysfunction of outflow. Patients with IHD had lower DAC as the result of elevation of local peripheral resistanse and reduction of microcirculation [7].

Table 8. Data of DC in patients with IHD and DLD

\begin{tabular}{|c|c|c|c|c|}
\hline \multirow{2}{*}{ Data of DC } & \multicolumn{5}{|c|}{ Groups } \\
\cline { 2 - 5 } & $\begin{array}{c}\text { IHD } \\
\mathrm{n}=30\end{array}$ & $\begin{array}{c}\text { IHD }+\mathrm{DLD} \\
\mathrm{n}=25\end{array}$ & $\begin{array}{c}\text { DLD } \\
\mathrm{N}=102\end{array}$ & $\begin{array}{c}\text { Healthy volunteers } \\
\mathrm{n}=30\end{array}$ \\
\hline $\begin{array}{c}\mathrm{DAC}, \mathrm{mcm} \\
\mathrm{M} \pm \mathrm{SD}\end{array}$ & $11,2 \pm 5,4^{\wedge}$ & $14,1 \pm 3,1^{*}$ & $13,7 \pm 4,3^{\#}$ & $12,5 \pm 2,3$ \\
\hline $\begin{array}{c}\mathrm{DVC}, \mathrm{mcm} \\
\mathrm{M} \pm \mathrm{SD}\end{array}$ & $13,5 \pm 4,7^{\wedge}$ & $16,8 \pm 5,2^{*}$ & $14,6 \pm 6,5$ & $15,1 \pm 3,9$ \\
\hline $\mathrm{LAC}, \mathrm{mcm}$ & $317(190-475)^{*} \wedge$ & $353(210-505)^{*}$ & $284(183-526)^{*} \wedge$ & $402(207-611)$ \\
\hline $\mathrm{LVC}, \mathrm{mcm}$ & $321(185-405)^{*} \wedge$ & $382(279-483)^{*}$ & $292(197-404)^{*}$ & $455(216-701)$ \\
\hline FVAC, $\mathrm{mcm} / \mathrm{s}$ & $380(122-476)^{*}$ & $326(202-605)^{*}$ & $365(122-586)^{*}$ & $612(349-950)$ \\
\hline FVVC, $\mathrm{mcm} / \mathrm{c}$ & $270(219-431)^{*}$ & $310(210-658)^{*}$ & $350(219-567)^{*}$ & $560(350-890)$ \\
\hline
\end{tabular}

Abbreviations: continuous variables were expressed as median (interquartile range).

$* u<0,05$ comparing to the control with Vilkokson-Mann-Witney criterion.

$\wedge \mathrm{u}<0,05$ comparing to the subgroup IHD+DLD.

${ }^{\#} \mathrm{u}<0,05$ comparing to the subgroup IHD.

According to the results of our analyses (Table 9) patients with EF $>40 \%$, IHD and DLD had accelerated data of DAC, lower data of FVAC as the result of decreasing of arteriole tone and dilatation of precapillary sphincters. It could be caused by the changes of liver function with elevation of vasodilatators such as nitric oxide, prostacyclin and glucagon and decreased sensitivity of arteriole to the catecholamines and angiotensin-II etc. [7]. Patients with EFlv $<40 \%$ with DLD had lower data of FVAC due to the decreased tone (paresis) of precapillary sphincters and decreased FVVC as a result of stasis (disturbed venous outflow). It could be caused by hyperproduction of tumornecrotic-factor- $\alpha$ and interleukines-1,6,8, metabolism disturbances of vasoconstrictors by the damaged liver. That is why patients have structural changes of capillaries such as bi-, trifurcation and bushy forms. Patients with IHD and stages of EFlv decrease had clear signs of reduction blood supply due to the disturbances of central hemodynamics, atherosclerosis of vessels and elevation of its tone. In patients with IHD and DLD we didn't find the decreasing of DC data according to the lowering of EFlv.

Patients with IHD and DLD with EFlv $>40 \%$ had tendency to the decrease of vessels' tone and microcirculation compared to the patients without DLD due to the oedema of Disse's space, reduced numbers of star-shaped cells, metabolism disorder of extracellular matrix-proteins, chemokines, cytokines, liver fibrosis. 
Table 9. Data of DC in patients with IHD depending on the presence of concomitant DLD and EFlv

\begin{tabular}{|l|c|c|c|c|c|}
\hline \multirow{2}{*}{ Data of DC } & \multicolumn{2}{|c|}{ IHD EF $>40 \%$} & \multicolumn{2}{c|}{ IHD EF $<40 \%$} & \multirow{2}{*}{ Control } \\
\cline { 2 - 5 } & With DLD & without DLD & with DLD & without DLD & \\
\hline Mediana & $\mathrm{N}=13$ & $\mathrm{n}=14$ & $\mathrm{n}=12$ & $\mathrm{n}=16$ & $\mathrm{n}=30$ \\
\hline $\begin{array}{l}\mathrm{D} A C, \mathrm{mcm} \\
\mathrm{M} \pm \mathrm{SD}\end{array}$ & $14,7 \pm 2,7^{*}$ & $11,2 \pm 3,9^{* \dagger}$ & $13,1 \pm 6,8$ & $10,1 \pm 2,3^{*}$ & $12,5 \pm 2,3$ \\
\hline $\begin{array}{l}\mathrm{DVC}, \mathrm{mcm} \\
\mathrm{M} \pm \mathrm{SD}\end{array}$ & $17,3 \pm 6,0^{*}$ & $14,1 \pm 5,0$ & $15,2 \pm 4,5^{*}$ & $12,9 \pm 4,7$ & $15,1 \pm 3,9$ \\
\hline $\mathrm{LAC}, \mathrm{mcm}$ & $353(240-505)^{*}$ & $228(201-378)$ & $327(210-475)^{*}$ & $301(247-479)^{*}$ & $402(207-611)$ \\
\hline LVC, $\mathrm{mcm}$ & $382(279-550)^{*}$ & $237(190-388)$ & $364(279-502)^{*}$ & $324(238-482)^{*}$ & $455(216-701)$ \\
\hline FVAC, $\mathrm{mcm} / \mathrm{s}$ & $341(282-605)^{*}$ & $408(181-650)^{*}$ & $297(202-572)^{*}$ & $380(211-495)^{* \dagger}$ & $612(349-950)$ \\
\hline FVVC, $\mathrm{mcm} / \mathrm{c}$ & $335(307-658)^{*}$ & $381(145-473)^{*}$ & $258(210-591)^{*}$ & $302(185-410)^{*}$ & $560(350-890)$ \\
\hline
\end{tabular}

Abbreviations: continuous variables were expressed as median (interquartile range).

$* \mathrm{u}<0,05$ comparing to the control with Vilkokson-Mann-Witney criterion.

${ }^{\dagger} \mathrm{u}<0,05$ comparing to the oaients with IHD and without DLD similar to the EFlv.

According to the results of DC data in patients with DLD of different etiology (Table 10) the worst stage of hemodynamic disorder was revealed in patients with LC. In groups with CTH and NASH the DAC was the biggest due to the disorder of liver utilization of glucagon, prostaglandins, adenosine, biliary acids and etc.

Table 10. Data of DC in patients with DLD of different etiology

\begin{tabular}{|c|c|c|c|c|c|}
\hline Data of DC & $\begin{array}{c}\text { DLD 1C } \\
\mathrm{n}=14\end{array}$ & $\begin{array}{c}\text { Viral hepatitis } \\
n=43\end{array}$ & $\begin{array}{c}\text { Chronic toxic } \\
\text { hepatitis } \\
n=21\end{array}$ & $\begin{array}{c}\text { NASH } \\
n=26\end{array}$ & $\begin{array}{l}\text { Control } \\
\text { group } \\
\mathrm{n}=30\end{array}$ \\
\hline $\begin{array}{l}\text { DAC, mcm } \\
\mathrm{M} \pm \mathrm{SD}\end{array}$ & $10,7 \pm 4,1^{\text {*\#市 }}$ & $13,0 \pm 6,1^{\wedge}$ & $14,4 \pm 5,2^{*} \wedge$ & $15,1 \pm 4,3^{*} \wedge$ & $12,5 \pm 2,3$ \\
\hline $\begin{array}{l}\mathrm{DVC}, \mathrm{mcm} \\
\mathrm{M} \pm \mathrm{SD}\end{array}$ & $12,8 \pm 5,5^{* \# \dagger}$ & $14,3 \pm 5,2^{\wedge}$ & $15,7 \pm 4,9^{\wedge}$ & $16,2 \pm 4,1^{* \wedge}$ & $15,1 \pm 3,9$ \\
\hline $\mathrm{LAC}, 1_{1}$ & $265(183-471)^{* \#}$ & $374(201-584)^{\wedge}$ & 194(189-307) ${ }^{* \wedge}$ & $284(183-526)^{*}$ & $402(207-611)$ \\
\hline $\mathrm{LVC}, \mathrm{mcm}$ & $278(180-364)^{*}$ & $380(217-420)^{\wedge}$ & $216(197-328)^{* \wedge}$ & $292(197-404)^{*}$ & $455(216-701)$ \\
\hline $\mathrm{FVAC}, \mathrm{mcm} / \mathrm{s}$ & $165(122-386)^{*}$ & $539(470-578)^{\wedge}$ & $341(145-450)^{* \wedge}$ & $403(218-517)^{* \wedge \dagger}$ & $612(349-950)$ \\
\hline FVVC, $\mathrm{mcm} / \mathrm{c}$ & $158(219-277)^{*}$ & $528(306-560)^{\wedge}$ & $332(228-439)^{*} \wedge$ & $377(219-503)^{* \wedge \#}$ & $560(350-890)$ \\
\hline
\end{tabular}

Abbreviations: continuous variables were expressed as median (interquartile range).

$*_{\mathrm{u}}<0,05$ comparing to the control with Vilkokson-Mann-Witney criterion.

$\wedge \mathrm{u}<0,05$ comparing to the patients with LC.

${ }^{\dagger} \mathrm{u}<0,05$ comparing to the patients with viral hepatitis.

\# $\mathrm{u}<0,05$ comparing to the patients with chronic toxic hepatitis.

In our study we revealed (Table 11) that with DLD of minimal liver damage had slighter changes of DAC, DVC, FVAC and FVVC compared to the patients with LC due to the decreased tone of precapillary sphincters and elevation of capillary blood supply. Patients with moderate syndrome of cytolysis/cholestasis had slighter disorder of venous outflow, decreasing of peripheral resistance of precapillaries according to the DAC and DVC data and capillary microcirculation according to the FVAC and FVVC compared to the patients with LC due to the hyperproduction of the proinflammatory cytokines. Elevation of liver damage was characterized by phases changes of DAC, FVVC and FVAC due to the hyperactivity of L-arginine-NO and depletion of reticulo-endothelial system of liver in heavy hepatitis and LC [8-10]. The highest stage of liver blood supply dysfunction was in patients with LC due to the hyperproduction and/or disorder of vasoconstrictor utilization and structural and functional changes in the liver [11-14].

Table 11. Data of DC in patients with DLD to the stages of liver damage

\begin{tabular}{|l|c|c|c|c|}
\hline Data of DC & $\begin{array}{c}\text { DLD LC } \\
\mathrm{n}=12\end{array}$ & $\begin{array}{c}\text { DLD of moderate } \\
\text { liver damage } \\
\mathrm{n}=38\end{array}$ & $\begin{array}{c}\text { DLD of minimal liver } \\
\text { damage } \\
\mathrm{n}=52\end{array}$ & $\begin{array}{c}\text { Control group } \\
\mathrm{n}=30\end{array}$ \\
\hline $\begin{array}{l}\mathrm{DAC}, \mathrm{mcm} \\
\mathrm{M} \pm \mathrm{SD}\end{array}$ & $10,7 \pm 4,1^{*}$ & $15,6 \pm 4,3^{* \wedge}$ & $14,8 \pm 4,3^{\#}$ & $12,5 \pm 2,3$ \\
\hline $\begin{array}{l}\mathrm{DVC}, \mathrm{mcm} \\
\mathrm{M} \pm \mathrm{SD}\end{array}$ & $12,8 \pm 5,5^{*}$ & $16,1 \pm 3,1^{\wedge}$ & $15,0 \pm 3,9^{\#}$ & $15,1 \pm 3,9$ \\
\hline $\mathrm{LAC}, \mathrm{mcm}$ & $265(183-471)^{*}$ & $302(198-417)^{*}$ & $285(185-391)^{*}$ & $402(207-611)$ \\
\hline $\mathrm{LVC}, \mathrm{mcm}$ & $278(180-364)^{*}$ & $310(217-412)^{*}$ & $288(189-405)^{*}$ & $455(216-701)$ \\
\hline FVAC, $\mathrm{mcm} / \mathrm{s}$ & $165(122-386)^{*}$ & $518(122-586)^{*}$ & $412(218-517)^{*} \wedge$ & $612(349-950)$ \\
\hline FVVC, $\mathrm{mcm} / \mathrm{c}$ & $158(219-277)^{*}$ & $484(219-567)^{* \#}$ & $403(219-503)^{*} \wedge$ & $560(350-890)$ \\
\hline
\end{tabular}


Abbreviations: continuous variables were expressed as median (interquartile range).

$*^{*}<0,05$ comparing to the control with Vilkokson-Mann-Witney criterion.

$\wedge \mathrm{u}<0,05$ comparing to the patients with LC.

${ }^{\#} \mathbf{u}<0,05$ comparing to the patients with DLD of moderate and minimal damage.

In our study correlation analyses demonstrated significant correlation of the data of DC and echo (Table 12) and could be the bases for further investigation of diagnostic value of DC in evaluation of intracardiac hemodynamic and capillary circulation.

Table 12. Correlation analyses of the data of DC and echo depending on the etiology of the disease

\begin{tabular}{|l|l|l|}
\hline $\begin{array}{l}\text { Patients with IHD } \\
\mathrm{n}=30\end{array}$ & $\begin{array}{l}\text { Patients with IHD and DLD } \\
\mathrm{n}=25\end{array}$ & $\begin{array}{l}\text { Patients with DLD } \\
\mathrm{n}=102\end{array}$ \\
\hline $\begin{array}{l}\text { DAC and EFlv }(\mathrm{r}=0.6 ; \mathrm{p}<0.05) . \\
\text { LA and FVAC }(\mathrm{r}=-0.41 ; \mathrm{p}<0.05) .\end{array}$ & $\begin{array}{l}\text { DVC and E/A }(\mathrm{r}=0,42 ; \mathrm{p}<0.05) . \\
\text { FVVC and Tivs }(\mathrm{r}=0.47 ; \mathrm{p}<0.05) .\end{array}$ & $\begin{array}{l}\text { RV and } \mathrm{DAC}(\mathrm{r}=0.39, \mathrm{p}<0.05) . \\
\text { DAC and } \mathrm{VCI}(\mathrm{r}=0.31, \mathrm{p}<0.05) .\end{array}$ \\
\hline
\end{tabular}

Abbreviations: $r$ - Pearson's correlation coefficient.

Conclusions. So, we revealed in our study that patients with IHD and reduction of contraction of LV and its diastolic filling had progressive microcirculatory supply disorder. There was also found that concomitant DLD in patients with IHD worsened significantly systolic and diastolic functions of LV, aggravated CHI, especially in patients with LC. In our investigation it was proved that presence of IHD and DLD caused disorder of cytomicroarchitectonics of the capillaries. We demonstrated value of DC in investigation of microcirculatory disorders to detect stages of blood supply disorders and to be noninvasive device for monitoring patients with IHD and concomitant DLD.

\section{REFERENCES}

1. Sanchez-Garcia ME, Ramirez-Lara I, Gomez-Delgado F et al. Quantitative evaluation of capillaroscopic microvascular changes in patients with established coronary heart disease.2018 Feb 23;150(4):131-137. doi: 10.1016/j.medcli.2017.06.068. Epub 2017 Sep 1. English, Spanish.

2. Gorshkov AY, Klimushina MV, Boytsov SA et al. Increase in perfused boundary region of endothelial glycocalyx is associated with higher prevalence of ischemic heart disease and lesions of microcirculation and vascular wall. Microcirculation. 2018 May;25(4):e12454. doi: 10.1111/micc.12454.

3. Held M, Bender D, Krauß S et al. Quantitative Analysis of Heel Skin Microcirculation Using Laser Doppler Flowmetry and Tissue Spectrophotometry. Adv Skin Wound Care. 2019 Feb; 32(2):88-92. doi:10.1097/01.ASW.0000549610.99102.01.

4. Petrischev N. Physiology and pathophysiology of endothelium. Dysfunction of endothelium. Etiology, mechanisms. Pharmacological therapy. - S.-P. 2003: 338.

5. Amosova E. Intracardiac hemodynamic in patients with diffuse liver diseases. Materials of Ukrainian therapeutists. 1998: 80- 81 .

6. Patt B.T., Jarjoura D., Haddad D.N. et al. Endothelial dysfunction in the microcirculation of patients with obstructive sleep apnea. Amer J of Resp and Crit Care Med. 2010. 182: 1540-1545. doi: 10.1164/rccm.201002-0162OC.

7. Thijssen D.H., Green D.J., Hopman M.T. Blood vessel remodeling and physical inactivity in humans. J of Appl Phys. 2011. 111: 1836 - 1845. doi: 10.1152/japplphysiol.00394.2011.

8. Scalia R. The microcirculation in adipose tissue inflammation. Rev in Endo and Met Dis. 2013. 14:69-76. doi: 10.1007/s11154-013-9236-X.

9. Kulikov D., Glazkov A., Dreval A. et al. Approaches to improve the predictive value of laser Doppler flowmetry in detection of microcirculation disorders in diabetes mellitus. Clin Hemor and Microc. 2018. 70 (2): 173-179.

10. Sorelli M, Francia P, Bocchi L et al. Assessment of cutaneous microcirculation by laser Doppler flowmetry in type 1 diabetes. Microvasc Res. 2019 Jul; 124:91-96. doi: 10.1016/j.mvr.2019.04.002. Epub 2019 Apr 6.

11. Babak O. Cirrhos pecheni i ego oslozhnenija. - K. 2011: 576

12. Abragamovich O. Stan sistemi krovoobigu y chvorich na difuzni urazhennia pechinki: ogliad suchasnoi literature ta opis vlasnogo klinichnogo vipadku. Lviv med Chasopis. 2011; 3:114-125.

13. Plotnikova E. Virazhennost adaptacionnih narushenii pri cirrhoze pecheni. Clin perspektivi gastroenter, hepat. 2013; 3: 10-17.

14. Kitura O. Strukturno-funkcionalnoe sostoyanie miocarda u bolnih chronicheskim hepatitom i cirrhosom pecheni. Vestnik problem biol i med. 2014;3(112): 131-134. 